\title{
シンプレックス法に基づいた 接触力計算のための凸多面体間衝突検出
}

\author{
船木 陸 議*1 松 野 文 俊*2
Simplex-Based Collision Detection to Contact Force Computation between Convex Polyhedra

\author{
Michitaka Funaki $^{* 1}$ and Fumitoshi Matsuno ${ }^{* 2}$
}

\begin{abstract}
The remaining aspect of robot simulation is calculating external force from environment. Two major subproblems of this are detecting collisions and computing collision forces. Although studied in isolation, these problems are closely related in simulation. This paper presents a method for fitting the pieces together on the rigid bodies which are formed convex polyhedron and covered with rubber-like material. We consider that the collision force between such objects is the function of the intersection of those, therefore calculating the collision force comes to finding the shape of the convex polyhedron because the intersection of two convex polyhedra is also a convex polyhedron. In order to find the shape of the convex polytope, we propose an approach based on the revised simplex method, which computational cost is approximately linear in the total number of faces.
\end{abstract}

Key Words: Robot Simulation, Collision Detection, Collision Force, Convex Polyhedron, Simplex Method

\section{1.は じめに}

歩行ロボットの足裏 [1] や多指ハンド $[2]$ など, 環境との接触 が想定される部位には，しばし適度なコンプライアンスと摩擦 を確保するためにゴム様物質が張り付けられる。ゴムは結晶構 造の物質と違い, 外力を受けた部位が局所的に大変形する $[3]$. 直方体形状のゴムどうしの接触の様子を Fig. 1 に示す. 2 物体 は，あたかも，それぞれが変形せずに空間内で交差しているよ うに見える(Fig. 2).ゴムは内部の粘性が大きく，衝突によっ て発生する収縮膨張波は速やかに消滅するので，衝突は準静的 に扱ってよいことが知られており [3], 衝突を準静的に扱う限り 2 物体の接触力は 2 物体の変形によるわけであるが，その変形 が 2 物体の交差部分として近似できるのであれば，接触力もま た 2 物体の（時間的履歴を含めた）交差部分の関数で近似でき るはずである.

接触力を 2 物体の交差部分の関数とするこの接触力モデル はスプリング法 [4] の自然な拡張でもある. スプリング法（あ るいはペナルティ (Penalty) 法) は, 物体の接触点 (Contact Point 以後 CP）に仮想的なスプリングを考え，このスプリング

原稿受付 2003 年 5 月 22 日

*1長岡技術科学大学 機械系

$* 2$ 電気通信大学電気通信学部知能機械工学科

${ }^{* 1}$ Nagaoka University of Technology, Department of Mechanical Engineering

${ }^{* 2}$ University of Electro-Communications, Department of Mechanical Engineering and Intelligent Systems
が接触力を発生すると考えるモデルである，スプリングは，物 体が接触すると $\mathrm{CP}$ に出現し，接触する 2 物体が互いに離れる 方向に力を発生し (Fig. 3 (A)), 物体が完全に離れると消滅す る (Fig. 3 (B) ) とする. ばね定数は, 物体間の減り込みがあま り大きくならないよう適当に決められる，直観的に理解しやす

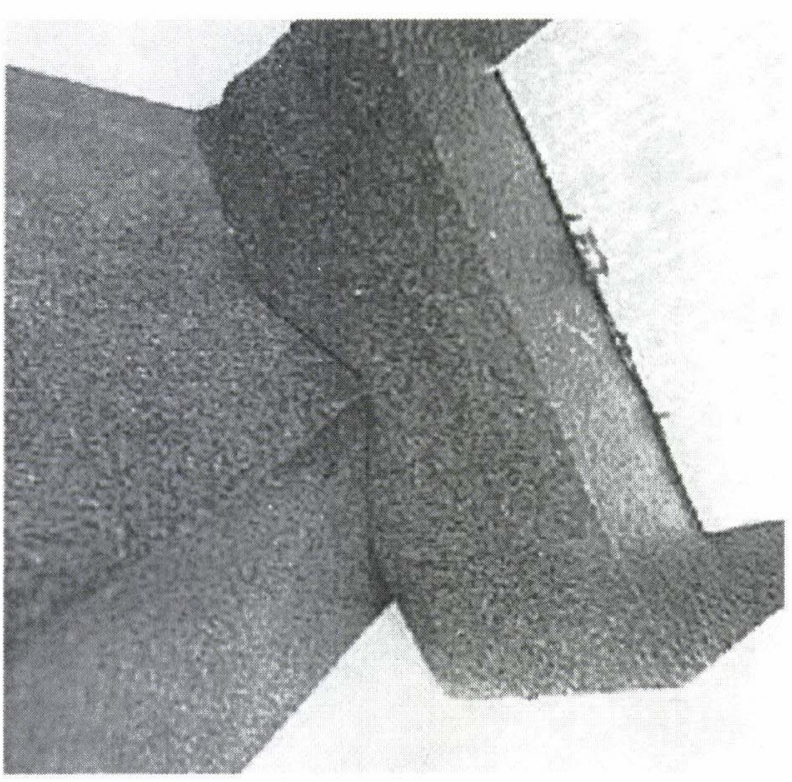

Fig. 1 Contact between 2 rubber blocks 


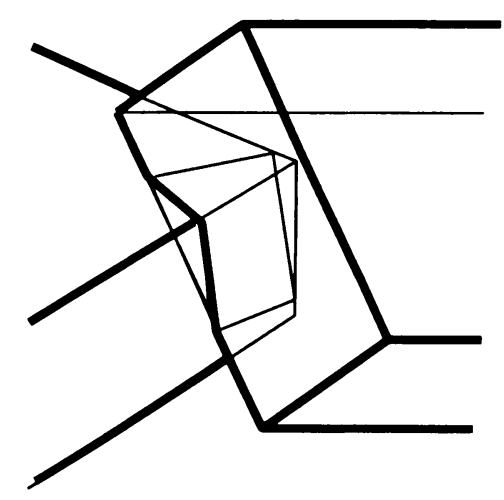

Fig. 2 Perspective of Fig. 1

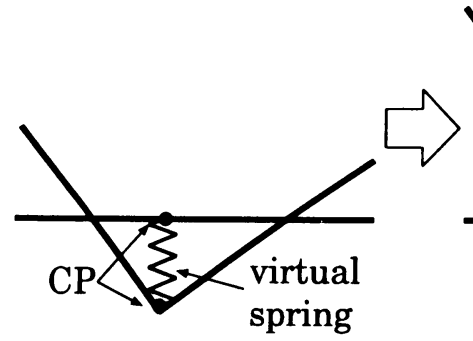

(A)
(B)

Fig. 3 Penalty method (A) A virtual spring is attached between the CPs, and the spring attempts to push them apart. (B) If the bodies move apart, the spring disappears

く，床や壁などの半空間に対する衝突検出に限っては実装が簡 単なため, 簡易な衝突検出および衝突力計算モデルとしてよく 採用されるが [5] [6], Fig. 2のような辺と辺の衝突を扱うのは不 得意であり，そして，そもそも物理的根拠に乏しい [7]一 [9]. 対 して，接触力を 2 物体の減り込み深度のみの関数とするのでは なく, 交差部分そのものの関数とすることは, 前述の観察から 十分な物理的根拠を持つ.

この接触力モデルをロボットシミュレータに適用する際, 次 の二つが問題になる.

(1) 交差部分の計算

（2）接触力の関数形の決定

交差部分は，接触が存続するすべての時間刻みで計算されねば ならず，接触力の計算に先行する衝突判定と合わせて効率のよ い計算方法が確立されねばならない。単なる衝突判定は既に多 くの研究 $[9] \sim[19]$ があるが, 交差部分の形状も必要であるから 問題はより難しい.

多面体間の最短距離計算法と衝突判定法は, CG アニメーショ ンやロボットシミュレーション等の要請から, 計算幾何学の一 大分野として盛んに研究され，ロバストで十分実用的な速さの 計算手法が，既に多数開発されている [12] [13] [16] [17]. サーベ イ [18] では, 計算幾何学の次なる課題として, ダイナミックシ ミュレーションにおける衝突力計算のための最短距離, 接触点 部位および減り込み深度のロバストでインタラクティブな計算 方法の開発を挙げている．本論文では，この接触力計算に供す るために, 単なる減り込み深度ではなく, 問題点 (1) の交差部 分の完全な形状を十分実用的な速さでロバストに計算する手法
を提案する．提案手法は，ロボットシミュレータでの利用を考 慮し，物体の形状を凸多面体に限定することによって，数十面 程度までの計算速度と, 数值計算上のロバスト性を有している. 提案手法の計算原理は改訂シンプレックス法を幾何学的に解釈 することにより得られるもので，アルゴリズム的にロバストで ある. シンプレックス法による単なる衝突判定 [20] とは違い, すべての頂点を求めるため計算量は 2 物体の面の総数の 2 乗 に比例するが， 2 乗の係数は小さく，数十面程度であればほほ 1 乗と見なせる。実装は容易で，コード量は改訂シンプレック ス法のソルバー程度である。

問題点 (2) の関数形については, 本論文では論じない. 具体 的な関数形は理論的あるいは実験的に求めることになるであろ う、筆者らの提案する関数形とその検証実験は別報として報告 する予定である。

\section{2. 凸多面体の定義と性質}

本論文では, 線形連立不等式の解集合として凸多面体を定義 する.この定義により, 物体の形状定義, 衝突判定, 交差部分 の 3 種の計算が, すべて凸多面体の形状計算に帰着され, 統一 的に扱えるようになる。

\section{1 凸多面体の定義}

定義 $1 R^{n}$ において, 行列 $A \in R^{m \times n}$ とベクトル $b \in R^{m}$ が与えられたとき, 集合 $P=\left\{x \in R^{n} \mid A x \leq b\right\}$ を凸多面体 (convex polyhedron) と呼び $(A, b)_{P}$ などと書く. $A$ を係数 行列, $b$ を切片べクトル, 連立線形不等式 $A x \leq b$ を定義不等 式, $P$ の要素 $x \in P$ を $P$ の点あるいは解と呼ぶことにする. $m=1$ の凸多面体を特に半空間と呼ぶ.

定義 1 では，定義不等式が解を持つかどうかに関わらず，そ の解集合を凸多面体とするので，空集合も凸多面体であると考 える.

\section{2 積多面体}

二つの凸多面体の積集合は，それぞれの定義不等式を同時に 満たす解なので, やはり凸多面体になり, 次の性質が成り立つ.

性質 $1 \quad P_{1}=\left(A_{1}, b_{1}\right)_{P}, P_{2}=\left(A_{2}, b_{2}\right)_{P}$ に対して

$$
P_{1} \cap P_{2}=\left(\left[\begin{array}{l}
A_{1} \\
A_{2}
\end{array}\right],\left[\begin{array}{l}
b_{1} \\
b_{2}
\end{array}\right]\right)_{P}
$$

である(Fig. 4).

凸多面体どうしの積を積多面体と呼ぶことにしよう．性質 1 から, 物体の形状定義も, 物体の交差部分の計算もまったく同 じに扱えることが分かる。そして 2 物体が衝突しているかどう かはもはや 2 物体の積多面体が解を持つかどうかの判定に過ぎ ない.

\section{3 面，辺および頂点の定義}

$R^{n}$ の凸多面体 $P$ の定義不等式を $A x \leq b, A=$ $\left[\cdots, a_{i}^{T}, \cdots\right]^{T}, b=\left[\cdots, b_{i}, \cdots\right]^{T}$ とする. $i$ 番目の不等式 $a_{i} x \leq b_{i}$ が定める半空間の境界は $a_{i} x=b_{i}$ なる平面である. 凸多面体の表面は，この平面で特徵付けられる.

定義 $2 R^{n}$ の凸多面体 $P$ の定義不等式が $m$ 個の線形不等 式の集まりであるとする. $i \in\{1, \ldots, m\}$ 番目の不等式が定め る半空間の境界と $P$ が共通部分を持つとき, その共通部分を $P$ 


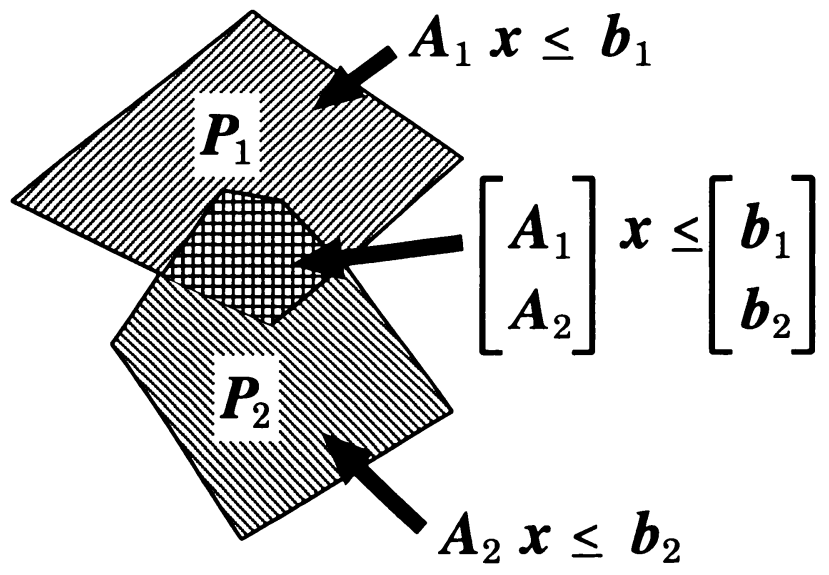

Fig. 4 Product polyhedron

の $(i$ 番目の) 面 (facet) と呼び $f\{i\}$ と記す. 相異なる $n-1$ 個の $P$ の面が共通部分を持つとき, その共通部分を $P$ の辺 (edge) と呼ぶ. 相異なる $n$ 個の $P$ の面が共通部分を持つと き, その共通部分を $P$ の頂点 (vertex) と呼ぶ.

$R^{3}$ の凸 $m$ 面体の辺と頂点の個数の上限を与えておこう.

性質 $2 m$ 個の不等式で定義される多面体の面の数 $F$, 頂点 の数 $V$, 辺の数 $E$ の上限は

$$
\begin{aligned}
& F \leq m \\
& V \leq 2(m-2) \\
& E \leq 3(m-2)
\end{aligned}
$$

である。

証明 $F$ の上限は明らか. $V$ の上限は McMullen の限界 式 [21] を三次元に適用して

$$
V \leq_{m-\left\lfloor\frac{3+1}{2}\right\rfloor} \mathbf{C}_{m-3}+{ }_{m-\left\lfloor\frac{3+2}{2}\right\rfloor} \mathbf{C}_{m-3}=2(m-2) .
$$

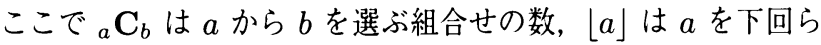
ない最小の整数である． $E$ の上限は $F$ と $V$ の上限を Euler の 多面体定理に代入して

$$
E=F+V-2 \leq m+2(m-2)-2=3(m-2)
$$

が得られる。

\section{4 稜グラフ}

$R^{3}$ の凸多面体の表面は $S^{2}$ と同相であるから，凸多面体の 頂点と辺を，それぞれ節と辺に対応させた平面グラフを描くこ とができる。このグラフを稜グラフ（Vertex-Edge Graph）と いい，辺と頂点と面の位相的な関係を表現できる [22]. すなわ ち，辺は辺に，頂点は節に，面は辺で册まれた領域に対応する (Fig. 5).

定義 2 から，一つの頂点は三つの面の交わりで生成される と考えることができる。一つの頂点で四つ以上の面が交わっ ている状態は複数の頂点が重なっている, すなわち退化 (degenerate）していると考えることにすれば（Fig.6)，頂点は 必ず三つの面の組で表現することができる．例えば 6 面体

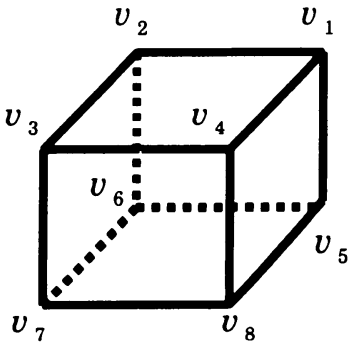

Polyhedron

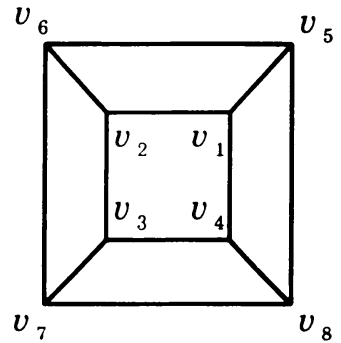

Vertex-Edge Ggraph
Fig. 5 A polyhedron and its vertex-edge graph
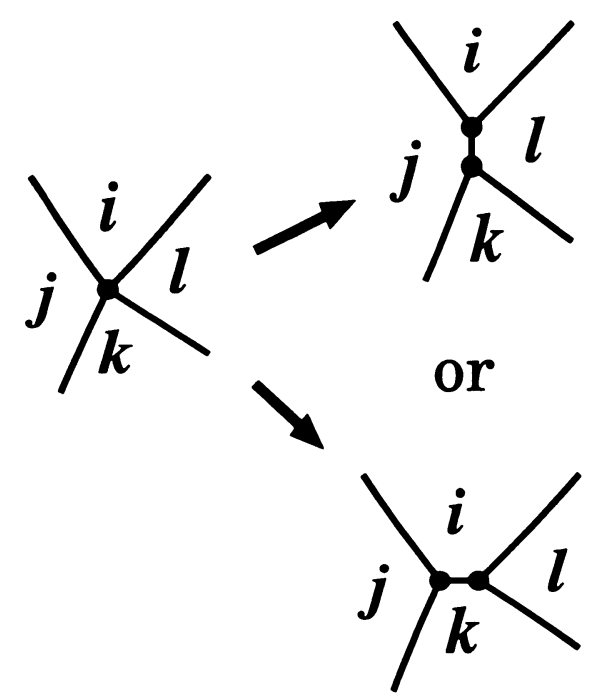

Fig. 6 A vertex where more than 3 planes intersect is interpreted as 2 or more verteces having degenerated into one

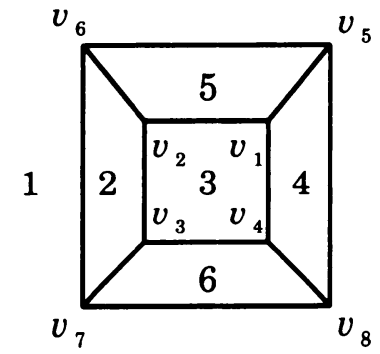

Fig. 7 Vertex-edge graph of cuboid

の各面が Fig. 7 のように整数を割り振られているとすると, 頂点 $v_{1}, v_{2}, v_{3}, v_{4}, v_{5}, v_{6}, v_{7}, v_{8}$ はそれぞれ頂点を構成する三 つの面の組として $\{3,4,5\},\{2,3,5\},\{2,3,6\}\{3,4,6\}$, $\{1,4,5\},\{1,2,5\},\{1,2,6\}\{1,3,6\}$ と表せる.この三つの 面の組を頂点の面座標と呼ぶことにする，面座標 $\{i, j, k\}$ であ る頂点を $v\{i, j, k\}$ で記す. 頂点のユークリッド座標は, 面座 標成分の 3 面（を表現する方程式）を連立させれば得られるか ら, $v\{i, j, k\}$ でそのユークリッド座標も表すことにする.

辺についても同様に二つの面の組で表現でき，面 $f\{i\}, f\{j\}$ の共通部分である辺を $e\{i, j\}$ と記す.

一つの頂点に対し，1 本の辺で結ばれた頂点を近傍あるいは 
隣の点などと呼ぶことにする．一つの頂点は 3 平面が交わる点 であるから，近傍は少なくとも 3 個存在する．四つ以上の近傍 を持つ頂点は，複数の頂点が退化していると考えることにすれ ば，すべての頂点は必ず 3 個の近傍を持つことになる.

退化していない頂点は単純（simple）であるという。すべて の頂点が単純な凸多面体を単純な凸多面体という。

\section{3. 凸多面体の形状計算}

$m$ 個の線形不等式が定義する凸多面体の形状計算には $O(m \log m)$ （より正確には最適計算量 $\theta(m \log m))$ の方法が 知られている [23]. しかし最適であるがゆえに退化頂点で数值 誤差の影響を受けやすく，アルゴリズムが破綻しないよう対策 すると（計算精度によっては） $O\left(m^{2}\right)$ になってしまう $[22] . ま$ た双対空間における凸包計算に帰着させているため, 主空間か ら双対空間への変換およびその逆変換が $O(m)$ で加算され, 計 算量は増加する。

主空間で計算する方法としては，シンプレックス法に基づい た方法 [21] がある。この方法ではシンプレックス法の凸多面体 の辺に沿って目的関数を最適化する頂点を探索する，という性 質を用いている，数值誤差にロバストであり，主空間で直接計 算するため双対変換等のオーバーヘッドはないが，1 頂点の探 索に $m$ 元連立一次方程式の解法が必要で, その係数の行列が スパースであることを用いても $O\left(m^{2}\right)$ であるから, 全頂点探 索に $O\left(\mathrm{~m}^{3}\right)$ の計算を要し，そのままでは実用性が低い.

本論文では, 三次元に特化することによって文献 [21] の方法 を $O\left(\mathrm{~m}^{2}\right)$ に改良する。提案する手法の漸近的挙動は二次であ るが, 二次の係数は小さく, ロボットシミュレータへの応用で は一次と見なせる。

提案する手法の概要を述べる，まず何らかの方法で頂点を一 つ見つける (初期頂点探索). 頂点が見つからなければ，その多 面体には解が存在しない. 頂点が見つかれば，稜グラフに対し て，その頂点を起点としたグラフ探索で残りの頂点をすべて求 める (頂点抽出). 形状を決定するには, 頂点の座標值とその接 続関係を求めなければならないが, CG 表現や体積計算などの 便を考え，境界を成す凸多角形を接続関係として採用する。そ のため最後に頂点を結んで凸多角形を生成する(凸多角形抽出).

以後, 係数行列を $A \in R^{m \times 3}$, 切片ベクトルを $b \in R^{m}$, 解 集合 $P=(A, b)_{P}$ は有界であるとする.ロボットの構成部品は すべて有界であるから, 有界な構成部品どうし，あるいは，構 成部品と床や壁などの半空間との積多面体も有界であり，この 仮定は一般性を失わない. 衝突判定は, 積多面体に対する初期 頂点探索時に判定できる. 頂点が見つかれば衝突していて, 頂 点が見つからなければ衝突していない.

\section{1 初期頂点探索}

有界な三次元凸多面体 $P=(A, b)_{P}$ の 1 頂点を見つけるに は, 適当な次元横べクトル $c \neq 0$ に対する次の線形計画問題：

maximize: $f(x)=c x$

subject to: $A x \leq b, \quad-\infty \leq x \leq \infty$

$$
\begin{aligned}
\text { maximize: } & g(x)=-b^{T} y \\
\text { subject to: } & -A^{T} y \leq-c^{T}, \quad-\infty \leq y \leq \infty
\end{aligned}
$$

を改訂シンプレックス法 [21] で解けばよい.

主問題において $P$ が空集合でなく, かつ有界であれば，任意 の $c \neq 0$ に対して $f(x)=c x$ を最大にする 1 頂点が存在する から, 双対問題でも最適解を与える基底添字が求まる. 求まっ た基底添字に対応する $P$ の面を連立させると $P$ の 1 頂点が得 られる。

$-A^{T}$ の行数は 3 , 列数は $m$ であるから, 双対問題の改訂シ ンプレックス法による計算量は $O(m)$ である.

\section{2 頂点抽出}

$m$ 個の平面線形不等式で定義される凸多面体の頂点の候補は ${ }_{m} \mathbf{C}_{3}$ 個あるが, 稜グラフに対して前段で見つかった頂点を起点 とするグラフ探索をすることによりむだな探索を省くことがで きる。

3.2 .1 近傍の計算

$R^{n}$ の凸多面体の辺を求めるには, 一般には $n-1$ 個の面を連 立させた不定方程式を解かねばならない。この問題を文献 [21] ではスラック変数を導入して $m$ 元連立一次方程式の解法に帰 着させたため, 一つの近傍を求めるのに $O\left(\mathrm{~m}^{2}\right)$ の計算を要し ている.

しかし，任意次元ではなく，三次元の凸多面体に限定すれば， 二つの面の連立不定方程式は初等的に解けるから, わざわざス ラック変数など導入せず, 以下のように直接求めていけばよい. まず $v\{i, j, k\}$ から $e\{i, j\}$ 方向のベクトル $d_{i j, k}$ は

$$
\begin{aligned}
u_{i j} & =a_{i}^{T} \times a_{j}^{T} \\
d_{i j, k} & =-\left(a_{k} u_{i j}\right) u_{i j} .
\end{aligned}
$$

であるから $e\{i, j\}$ の方程式は, パラメータ $t$ を用いて

$$
v\{i, j, k\}+t d_{i j, k}
$$

とかける. $d_{i j, k}$ 方向の近傍は $f\{i\}, f\{j\}, f\{k\}$ 以外の面と最 初に交わる点であり，また $v\{i, j, k\}$ から交点までの距離はパ ラメータ $t$ で計量できるので, 最小の $t$ を与える交点が近傍に なる. $f\{\ell\}$ との交点を与える $t$ は

$$
a_{\ell}\left(v\{i, j, k\}+t d_{i j, k}\right)=b_{\ell}
$$

を解いて

$$
t=\frac{b_{\ell}-a_{\ell} v\{i, j, k\}}{a_{\ell} d_{i j, k}}
$$

であり，最小の $t$ を与える $\ell$ を求めればよい.

$t=0$ あるいは, 最小の $t$ が複数存在するときは退化頂点で ある. 退化頂点では, 記号搔動法 (付録 $\mathrm{A}$ ) を適用し, 最も手 前の面を選ぶ.

残りの $e\{j, k\}, e\{k, i\}$ 方向についても同様に計算すること によって 3 近傍が求まる. 


\subsection{2 グラフ探索}

稜グラフに対して, 初期頂点探索で見つけた頂点を起点とす る深さ優先探索か幅優先探索を行って残りの頂点を求める. 個々 の頂点は，面座標で識別する。

例として Fig. 7 の 6 面体について幅優先探索した場合を以 下に示す（幅優先探索では, 探索済みの頂点を保存するために リストを用いるが，その時点でのリストの内容を文中の（）内 に示した）。

1. 初期頂点探索で見つけた頂点を $v_{1}$ とする. $v_{1}$ をリストに 入れる $\left(v_{1}\right)$.

2. リストの最初の要素 $v_{1}$ の近傍 $v_{5}, v_{2}, v_{4}$ をリストに追加す る $\left(v_{1} v_{5} v_{2} v_{4}\right)$.

3. リストの次の要素 $v_{5}$ の近傍 $v_{6}, v_{1}, v_{8}$ のうち $v_{1}$ は既にリス トに入っているので $v_{6}, v_{8}$ だけを入れる $\left(v_{1} v_{5} v_{2} v_{4} v_{6} v_{8}\right)$.

4. リストの次の要素 $v_{2}$ の近傍 $v_{6}, v_{3}, v_{1}$ のうち $v_{6}, v_{1}$ は既 に入っているので $v_{3}$ だけ入れる $\left(v_{1} v_{5} v_{2} v_{4} v_{6} v_{8} v_{3}\right)$.

5. リストの次の要素 $v_{4}$ の近傍 $v_{1}, v_{3}, v_{8}$ はすべて既に入って いるので追加しない.

6. リストの次の要素 $v_{6}$ の近傍 $v_{5}, v_{2}, v_{7}$ のうち $v_{5}, v_{2}$ は既 に入っているので $v_{7}$ だけ追加する $\left(v_{1} v_{5} v_{2} v_{4} v_{6} v_{8} v_{3} v_{7}\right)$.

7. $v_{8}, v_{3}, v_{7}$ についても同様に近傍を調べるも, 既にそのすべ ての近傍が入っており，探索が終了する（リストの長さが, 性質 2 が定める頂点数の上限に到達したので終了, として もよい).

上記の例では，すべての頂点に対して 3 近傍を探索したが, 初期頂点以外の頂点では， 3 近傍のうちの一つは既に探索済み であり，再度の探索は不要である。このむだな探索を避けるた めには，グラフ探索の過程で面の隣接行列 [24]を作成していけ ばよい. 面の隣接行列とは面 $f\{i\}$ と面 $f\{j\}$ が隣接している とき $(i, j)$ 成分が 1 , 隣接していないとき 0 となる対称行列で ある. 辺 $e\{i, j\}$ は隣接行列の $(i, j)$ 成分に対応する.グラフ 探索開始時, 隣接行列のすべての要素を 0 に初期化しておき, 辺 $e\{i, j\}$ をたどるごとに $(i, j)$ および $(j, i)$ 成分を 1 にして いく. 近傍の探索は, 対応する隣接行列の成分が 0 のときだけ 行えばよい.

初期頂点以外では, 式 (1) を $2(m-3)$ 回計算し, 頂点りス 卜の探索は，適当なハッシュ関数を定めることによって定時間 で実行できるから，全頂点の計算は $O\left(m^{2}\right)$ である。しかし式 (1) の 1 回の計算はたかだか数回の四則演算で得られるので, 二次の係数は極めて小さい.

\section{3 凸多角形抽出}

ある面 $f\{h\}$ に含まれる頂点は，面座標成分の一つに $h$ を 持つ，逆に頂点の面座標成分の一つが $h$ であれば，その頂点は 必ず面 $f\{h\}$ に含まれる，凸多面体において一つの面に含まれ る凸多角形は一つだけであるから，同一面成分を持つ頂点を集 め，その頂点群の凹包を求めればよい，凸包の計算には，頂点 のユークリッド座標を用いるよりも，次に定義する頂点の法線 ベクトルを用いると若干計算量を減らすことができる.

定義 3 頂点を生成する 3 面の法線ベクトルの和を頂点の法 線ベクトルと呼ぶ.

頂点群が含まれる面 $f\{h\}$ を含む平面 $H$ に適当に $x$ 軸を定
めておく. 頂点 $v$ の法線ベクトルの $H$ への正射影は, 定義か ら $v$ を挟む 2 本の辺の法線の和である. 辺の $x$ 軸とのなす角 は凸多角形内部を左に見ながら辺をたどるにつれ増加するから， $H$ 上で頂点の法線ベクトルの $H$ への正射影と $x$ 軸のなす角 を $\operatorname{Angle}(H, v)$ とすると, $\operatorname{Angle}(H, v)$ も凸多角形の内部を左 に見ながら増加する (Fig. 8). したがって $\operatorname{Angle}(H, v)$ で頂 点をソートすれば $f\{h\}$ が得られる. 退化した頂点には複数の 頂点べクトルが貼り付くが, それぞれが $x$ 軸となす角度にした がってソートされるので, 退化の影響は受けない.

具体的には次のように計算する. 面 $f\{h\}$ を含む平面 $H$ の 法線べクトルは $a_{h}^{T}$ であるから, $H$ を面座標成分に持つ頂点群 の $i$ 番目の頂点の法線べクトルを $n_{i}$ とすると Schmidt の直交 化法を用いて $\operatorname{Angle}\left(H, n_{i}\right)$ は

$$
\begin{aligned}
& e_{z}=a_{h}^{T} \\
& e_{x}=\frac{1}{\sqrt{1-\gamma^{2}}}\left(n_{1}-\gamma a_{h}^{T}\right), \quad \gamma=a_{h} n_{1} \\
& e_{y}=e_{z} \times e_{x} \\
& \operatorname{Angle}\left(H, n_{i}\right)=\operatorname{atan} 2\left(n_{i}^{T} n_{y}, n_{i}^{T} n_{x}\right)
\end{aligned}
$$

\section{と計算できる.}

頂点数を $V$ としたとき，頂点のユークリッド座標を用いる と, 各頂点は三つの面に含まれるから，それぞれ 3 回の凸包計 算に用いられ, その際, 各平面内に設けた原点からの差を計算 するため $9 V$ の減算が必要になる。一一方, 頂点の法線べクトル を用いると，頂点の法線ベクトルは三つの法線ベクトルの和な ので $6 V$ の加算で計算でき，すバての凸包計算に利用できる. $m$ 面体の各面の（凸多角形としての）頂点数の総和は $m$ 面
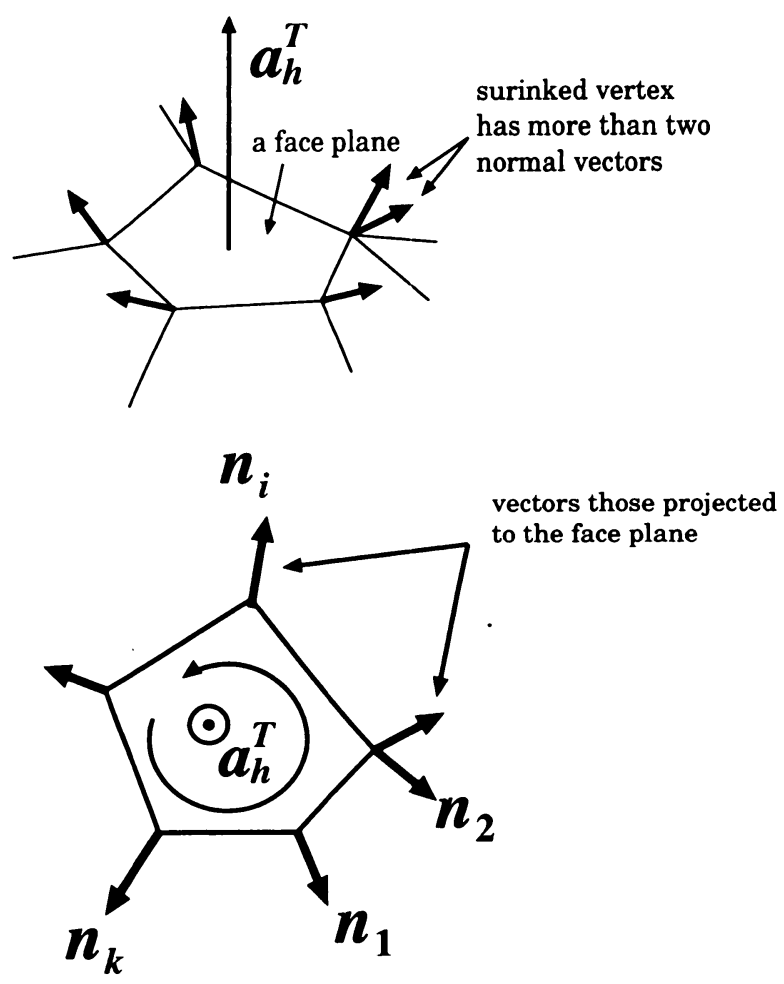

Fig. 8 Normal vector attatched to the vertex 
体の頂点をそれぞれ 3 回数えることになるので, 性質 2 よりた かだか $6(m-2)$ 個である．各面の（凸多角形としての）頂点 数は 3 以上 $m-1$ 以下であるから $O(m)$ 個の頂点数を持つ面 の個数は $m$ に無関係なたかだか定数個であり，そのソートに要 する計算量は $O(m \log m)$ である. Angle $(\cdot, \cdot)$ は钲時間で計算 でき，各頂点ごとに 3 回計算するから $O(m)$ の計算量である. したがって凸多角形抽出の全計算量は $O(m \log m)$ である.

\section{4. 計 算 量}

本論文で提案する手法を $\mathrm{C}++$ で記述し， $m$ 個の連立線形 不等式から $m$ 面体を計算するのに要する時間を計測してみる. $m$ 個の不等式は，単位べクトルを $a^{T}$ としたとき $a x \leq 1$ なる 形式とした。これは，原点を含み，単位球に外接する半空間を 表現するものであり，例えば $m=50$ で Fig.9 のような罒形 である。

プログラムは gcc 2.96 でコンパイルし, Pentium4 (2 [GHz]), メモリ 256 [MB] の PC（Linux 2.4.7-10）上で棒行した。計算 時間は gettimeofday( ) で取得し, 各 $m$ につき 1,000 回試行 したときの平均をとった. $5 \leq m \leq 120$ の計算時間を Fig. 10 に示す.また $5 \leq m \leq 20$ を拡大したものを Fig. 11 に示す.

初期頂点探索の $O(m)$, 頂点抽出の $O\left(m^{2}\right)$, 凸多角形抽出の $O(m \log m)$ から全計算時間は $O\left(m^{2}\right)$ であるが, Fig. 10 の増 加傾向はむしろ $O(m)$ 的である. 実際，二次多項式による最小 2 乗近似を求めると

$$
3.60 \times 10^{-4} m^{2}+6.31 \times 10^{-2} m-1.36 \times 10^{-1}[\mathrm{msec}]
$$

であり，二次の係数は一次の $1 / 120$ 以下であるから Fig. 10 に 示した範囲で計算量の増加は一次的と考えてよい.

スラック変数を用いた文献 $[21]$ の方法では，スパース行列で あることを用いても三次のオーダであり，また実際の計算時間 も $m=5$ で 0.31 [msec], $m=20$ で $2.50[\mathrm{msec}]$ と $m \geq 5$ の すべての場合で本手法より要する。

ロボットシミュレータへの応用を考えると $m$ は数十程度で 十分であろう。例えば 2 足歩行ロボットのリンクをすべて直方

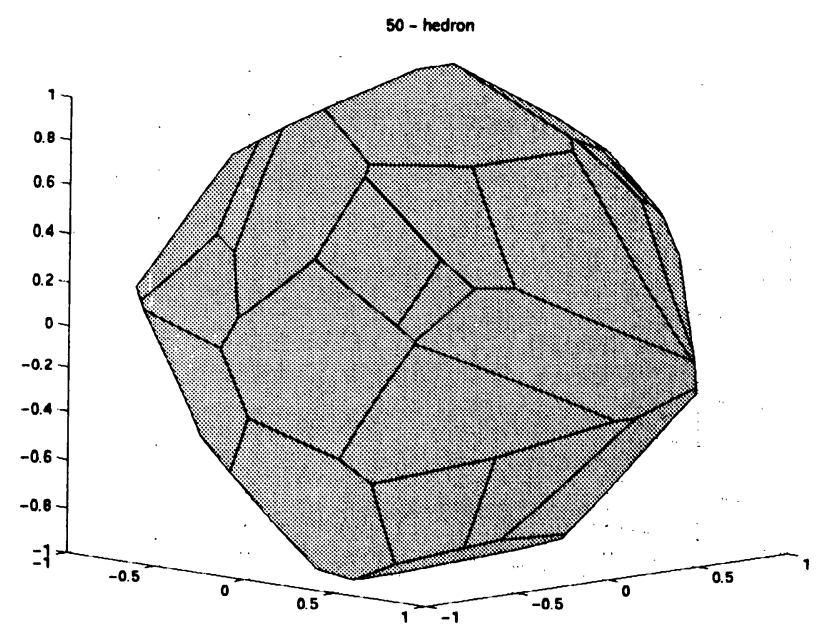

Fig. 9 An example of the convex polyhedron $(m=50)$ for calculation
体 (6 面体) で構成し，床 (半空間) の上を歩行させた場合に 生じる積多面体は, リンク間の衝突で 12 面体，足と床の衝突 で 7 面体である. なお， $m$ がこの程度の場合には, 従来の凸多 面体の形状計算の方法 [23]における双対空間への変換だけで本 手法の頂点抽出の計算時間を超えてしまう。

\section{5. ま と め}

シンプレックス法に基づいた接触力を計算するための凸多面 体間衝突検出法を提案した，提案する手法は，物体の形状を凸 多面体に制限するものの, 物体形状の定義, 衝突判定, 衝突力 計算を統一的に扱うことができる。計算量の最悪值の漸近解析 は二次であるが，二次の係数が極めて小さく，実用上一次と見 なせることを数值例で示した，プログラミングは容易で，例え ば Matlabならば退化対策のコードを含めて 200 行程（シンプ レックス法のソルバーを含めると 300 行程）で実装できる.

本手法をロボットシミュレータに適用する際には低コストな 簡易判定と組み合わせるとより効果的である。また，コヒーレ

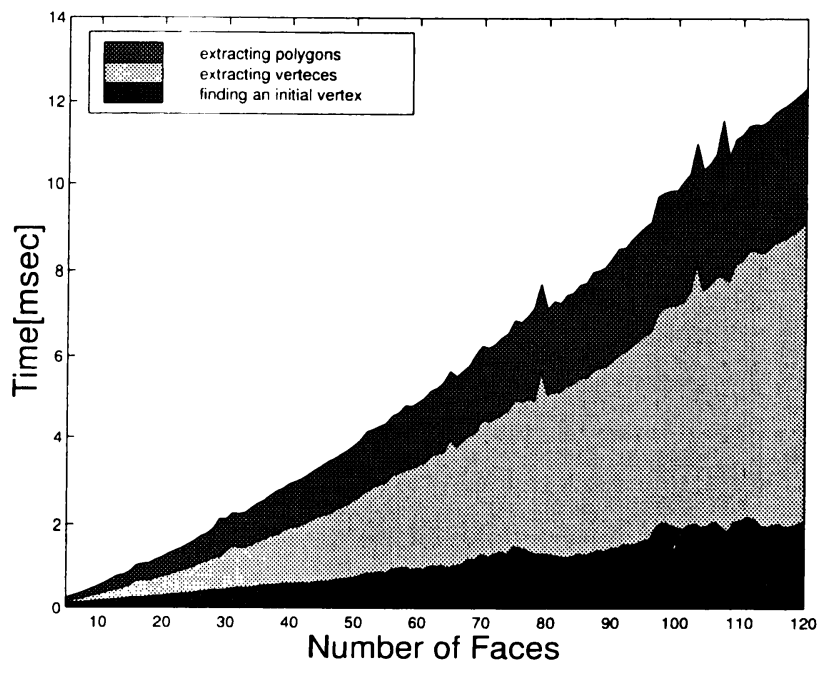

Fig. 10 Calculating time $(5 \leq m \leq 120)$

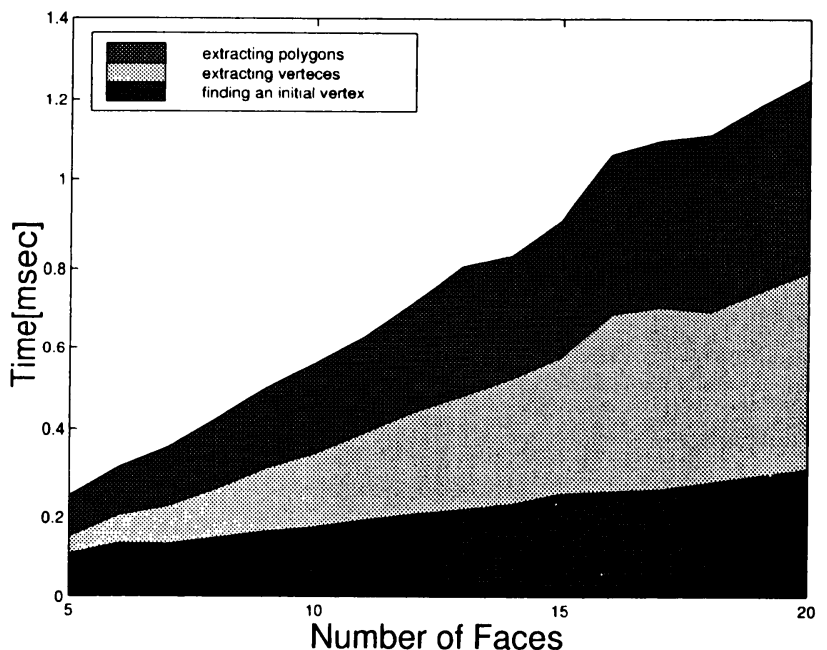

Fig. 11 Calculating time $(5 \leq m \leq 20)$ 
ントの利用 [14] [18] [19] [25] などさらなる高速化が可能である が，それらの手法については別報として報告する。

\section{参考 文 献}

[1] 広瀬真人, 竹中透, 五味洋, 小澤信明: “人間型ロボット”, 日本ロボッ 卜学会誌, vol.15, no.7, pp.983-985, 1997.

[2] R.M. Murray, Z. Li and S.S. Sastry: Robotic Manipulation. CRC Press, 1994.

[ 3 ] 久保完五：ゴム弾性 [初版復刻版]. 裳華房, 1946, 1996.

[4] M. Moore and J. Wilhelms: "Collision detection and response for computer animation," In Computer Graphics (Proc. ACM SIGGRAPH), vol.22, pp.289-298, August 1988.

[ 5 ] 黄潤潅, 加藤雅麗, 近野敦, 内山勝: “宇宙ロボティクスッールボックス spacedyna を用いたヒューマノイドロボットの動力学シミュレーショ ン”, 第 18 回日本ロボット学会学術講演会予稿集, pp.1463-1464, September 2000.

[6]福林寞喜, 北村新三, 中本裕之, 吳松保男: “神経振動子を用いた 2 足歩 行運動獲得”, 第 29 回知能システムシンポジウム資料, pp.195-200, March 2002.

[7] D. Baraff: "Analytical methods for dynamic simulation of nonpenetrating rigid bodies," In Computer Graphics (Proc. ACM SIGGRAPH), vol.23, pp.223-232, July 1989.

[8] P. Faloutsos, M. van de Panne and D. Terzopoulos: "Dynamic free-form deformations for animation synthesis," IEEE Transactions on Visualization and Computer Graphics, vol.3, no.3, pp.201-214, 1997.

[9] B. Mirtich: "Rigid body contact: Collision detection to force computation," Technical Report TR-98-01, Mitsubishi Electric Research Lab, Cambridge, MA, March 1998.

[10] E.G. Gilbert, D.W. Johnson and S.S. Keerthi: "A fast procedure for computing the distance between complex objects in three-dimensional space," IEEE Journal of Robotics and Automation, vol.4, no.2, pp.193-203, 1988.

[11] E.G. Gilbert and C.-P. Foo: "Computing the distance between general convex objects in three-dimensional space," IEEE Transactions on Robotics and Automation, vol.6, no.1, pp.53-61, 1990.

[12] J.D. Cohen, M.C. Lin, D. Manocha and M.K. Ponamgi: "ICOLLIDE: An interactive and exact collision detection system for large-scale environments," In Proc. ACM Int. 3D Graphics Conf., pp.189-196, April 1995.

[13] S. Gottschalk, M.C. Lin and D. Manocha: "Obbtree: A hierarchical structure for rapid interference detection," In Computer Graphics (Proc. ACM SIGGRAPH), pp.171-180, April 1996.

[14] M.C. Lin, D. Manocha, J. Cohen and S. Gottschalk: "Collision Detection: Algorithms and Applications," In Proc. Algorithms for Robotics Motion and Manipulation, pp.129-142, 1997.

[15] S. Cameron: "A comparison of two fast algorithms for computing the distance between convex polyhedra," IEEE Transactions on Robotics and Automation, vol.13, no.6, pp.915-920, 1997.

[16] S. Cameron: "Enhancing GJK: Computing minimum and penetration distances between convex polyhedra," In Proc. IEEE Int. Conf. Robotics and Automation, pp.3112-3117, April 1997.

[17] B. Mirtich: "V-Clip: Fast and robust polyhedral collision detection," Technical Report TR-97-05, Mitsubishi Electric Research Lab, Cambridge, MA, June 1997.

[18] M.C. Lin and S. Gottschalk: "Collision detection between geometric models: a survey," In Proc. IMA Conf. on Mathematics of Surfaces, vol.1, pp.602-608, 1998.

[19] P. Jiménez, F. Thomas and C. Torras: "3D Collision Detection: A Survey," Computer \& Graphics, vol.25, no.2, pp.269-285, 2001.

[20] R. Seidel: "Linear programming and convex hulls made easy," In Computational Geometry (Proc. 6th Ann. ACM Conf.), pp.211-215, 1990.
[21] V. Chvătal: Linear programming. W.H. Freeman and Company, 1983, 2000.

[22] 杉原厚吉：計算幾何工学. 培風館, 1994.

[23] F.P. Preparata and M. Ian Shamos: Computational Geometry - An Introduction -. Springer-Verlag, 1988.

[24] 竹中淑子：線形代数的グラフ理論. 培風館, 1989 .

[25] D. Baraff: Curved surfaces and coherence for non-penetrating rigid body simulation. In Computer Graphics (Proc. ACM SIGGRAPH), vol.24, pp.19-28, August 1990.

[26] H. Edelsbrunner: Algorithms in Combinatorial Geometry. Springer-Verlag, 1987.

[27] 比留川博久: “幾何アルゴリズム”, 日本ロボット学会誌, vol.16, no.7, pp.915-917, 1998.

\section{付録 A. 記 号 摂 動 法}

記号掑動法 [22], あるいは単純性の模做 (Simulating Simplicity）[26]は, 退化頂点を構成している平面群に無限小の拱動を与 え，仮想的に単純性を得る手法である. 本付録では文献 [22] [26] より計算量が少なくて済む摂動法を導入する.

辺 $e\{i, j\}$ に沿って近傍を探索したとき, 面 $f\{k\}$ が面 $f\{\ell\}$ よりも先に $e\{i, j\}$ に交わるのは. 頂点 $v\{i, j, k\}$ の值が $f\{\ell\}$ に関する定義不等式 $a_{\ell} x \leq b_{\ell}$ を満たし, かつ, 等号が成り立 たないときである。そこで判別式 $D(i, j, k, \ell)$ を

$$
D(i, j, k, \ell)=a_{\ell} v\{i, j, k\}-b_{\ell}
$$

と定義すれば $D$ の符号によって $f\{k\}, f\{\ell\}$ のどちらが先に交 わるかを判定できる.

$a_{i}=\left(a_{i 1}, a_{i 2}, a_{i 3}\right)$ などとすると $v\{i, j, k\}$ が存在するため の必要十分条件は

$$
\Delta=\left|\begin{array}{ccc}
a_{i 1} & a_{i 2} & a_{i 3} \\
a_{j 1} & a_{j 2} & a_{j 3} \\
a_{k 1} & a_{k 2} & a_{k 3}
\end{array}\right|
$$

が 0 でないことであり，このとき $v\{i, j, k\}$ を Cramer の公 式で表現し，式（A.1）に代入してまとめると

$$
D(i, j, k, \ell)=\frac{1}{\Delta}\left|\begin{array}{cccc}
a_{i 1} & a_{i 2} & a_{i 3} & -b_{i} \\
a_{j 1} & a_{j 2} & a_{j 3} & -b_{j} \\
a_{k 1} & a_{k 2} & a_{k 3} & -b_{k} \\
a_{\ell 1} & a_{\ell 2} & a_{\ell 3} & -b_{\ell}
\end{array}\right|
$$

を得る.さて，十分小さな $\varepsilon>0$ の多項式

$$
F(i, j, k, \ell ; \varepsilon)=\frac{1}{\Delta}\left|\begin{array}{cccc}
a_{i 1} & a_{i 2} & a_{i 3} & -b_{i}+\varepsilon^{i} \\
a_{j 1} & a_{j 2} & a_{j 3} & -b_{j}+\varepsilon^{j} \\
a_{k 1} & a_{k 2} & a_{k 3} & -b_{k}+\varepsilon^{k} \\
a_{\ell 1} & a_{\ell 2} & a_{\ell 3} & -b_{\ell}+\varepsilon^{\ell}
\end{array}\right|
$$

を導入すると，すべての頂点を単純化することができる．実 際, $F(i, j, k, \ell ; \varepsilon)$ は $\varepsilon$ に関して連続かつ $F(i, j, k, \ell ; 0)=$ $D(i, j, k, \ell)$ であるから, $D(i, j, k, \ell) \neq 0$ ならば, 十分小さ な $\varepsilon て ゙ ~ F(i, j, k, \ell ; \varepsilon)$ の符号は $D(i, j, k, \ell)$ の符号に一致する. また $F$ は $\varepsilon$ の多項式として五つの項を持つが $\varepsilon^{\ell}$ の係数が常に 1 であることから， $D=0$ であっても十分小さな $\varepsilon て ゙ ~ F \neq 0$ である.したがって $F$ による判定ではすべての頂点が単純に なる。 
$F$ の符号の計算の際は $\varepsilon$ の值は不要である。 $F$ は十分小さ な $\varepsilon$ の多項式であるから，0でない最小次数の項が支配的であ る.よって，昇幕に並べたときに最初に現れる0でない係数の 符号をとればよい.下記に MatLabのコード例を示す（係数行 列を $\mathrm{A}$ ，切片ベクトルを $\mathrm{b}$ とたた。た，判別式 $F$ の符号の みが意味をもつので，定義式中の $1 / \Delta$ は $\Delta$ とした）.

function ret $=F(A, b, i, j, k, 1)$

$i d x=[i j k ~ l] ;$

[dummy, si] $=\operatorname{sort}(i d x)$;

$X=[A(i d x,:),-b(i d x)]$;

$I=$ eye (4);

ret $=\operatorname{det}(I(\operatorname{si},:)) * \operatorname{det}(X(1: 3,1: 3))$;

$\mathrm{X}=\mathrm{X}(\mathrm{si},:)$;

$\mathrm{h}=1 ; \%$ 退化頂点ならば 2 からでも可

while 1 ,

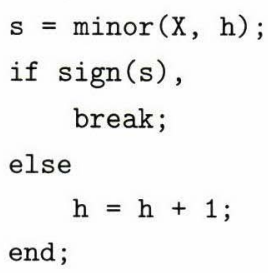

end;

ret $=$ ret $* \operatorname{sign}(s)$;

$\%$

function $\mathrm{y}=\operatorname{minor}(\mathrm{X}, \mathrm{k})$

if $\mathrm{k}==1$,

$\mathrm{y}=+\operatorname{det}(\mathrm{x}(1: 4,1: 4))$;

elseif $\mathrm{k}==2$,

$y=-\operatorname{det}\left(X\left(\left[\begin{array}{lll}2 & 3 & 4\end{array}\right], 1: 3\right)\right) ;$

elseif $\mathrm{k}==3$,

$y=+\operatorname{det}\left(X\left(\left[\begin{array}{lll}1 & 3 & 4\end{array}\right], 1: 3\right)\right) ;$

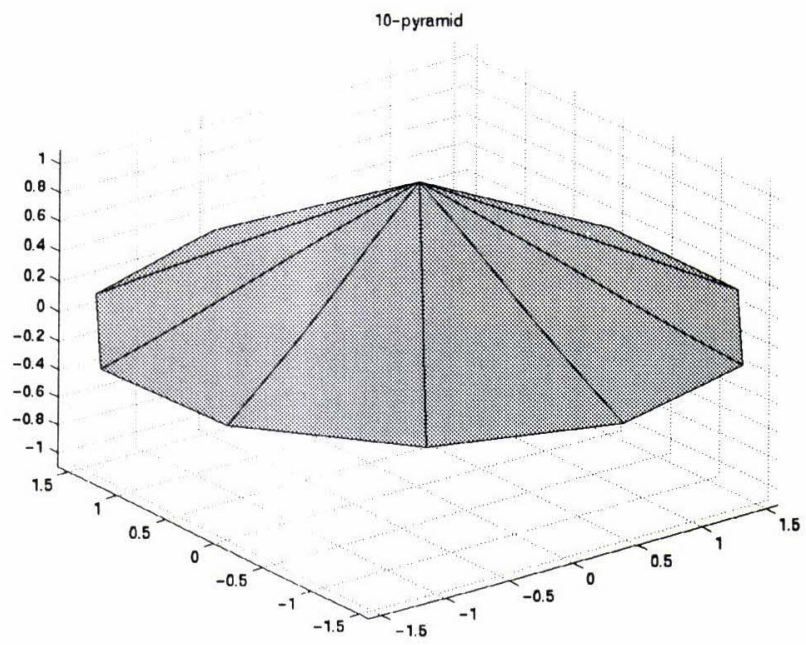

Fig. 12 An example of the pyramid $(n=10)$ for calculation

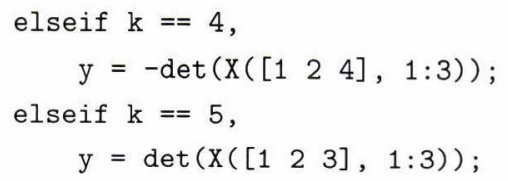

上記プログラムを， $n(5 \leq n \leq 120)$ 個の頂点が $(0,0,1)$ の 1 点で一つに退化している Fig. 12 のような $n$ 角錐 $(n+1$ 面 体）に適用したところ，すべての $n$ で性質 2 の上限が満たさ れていた。 また $F$ は第 2 項までに非負の係数が現れた。

文献 [22] [26] で定義されている判別式では, 係数行列にも摂 動を入れているため 34 個の項を持つが, 本判別式 $F$ は 5 個 の項しか持たず，より少ない計算で済む．実際，上記 $n$ 角錐の 計算で文献 [22] [26] の判別式では第 16 項まで計算する必要が あった。

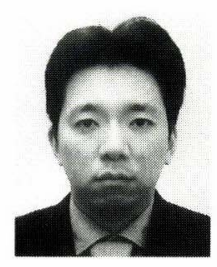

船木陸議 (Michitaka Funaki)

1967 年 9 月 12 日生. 1993 年大阪大学大学院基礎 工学研究科博士課程前期修了。同年日本電気株式 会社入社, 1994 年長岡技術科学大学助手 (機械系) となり現在に至る，宇宙ロボット，非ホロノミック システムの研究に興味を持つ. 計測自動制御学会会 員.

(日本ロボット学会正会員)

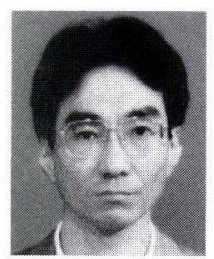

松野文俊（Fumitoshi Matsuno）

1957 年 7 月 26 日生. 1986 年大阪大学大学院基礎 工学研究科博士課程修了. 大阪大学基礎工学部助手, 神戸大学工学部講師, 助教授, 東京工業大学大学院 総合理工学研究科助教授を経て, 2003 年電気通信 大学教授（知能機械工学科）となり, 現在に至る. 主に，ロボティクス・制御理論・レスキュー学に関 する研究に従事. 2002 年より (NPO) 国際レスキューシステム研究 機構川崎ラボリーダ. 1989 年度日本ロボット学会研究奨励賞, 1993 年度システム制御情報学会論文賞, 1997 年度消防防災科学論文賞 (消 防庁長官表彰)，2001 年度計測自動制御学会論文賞・武田賞などを受 賞. IEEE, 計測自動制御学会, GIS 学会, 情報処理学会などの会員. 工学博士.

(日本ロボット学会正会員) 